\title{
AN ANALYSIS OF FACTORS AFFECTING SHU IN COOPERATIVES OF MICRO BUSINESS AND LABOR COOPERATIVE DEPARTMENT IN KEDIRI CITY
}

\author{
Stevanus Gatot Supriyadi., SE., M.Ak ${ }^{1}$, Dodik Jatmika ${ }^{2}$ \\ Universitas Kahuripan Kediri ${ }^{1}$, STIMI Banjarmasin ${ }^{2}$ \\ Email : $\underline{\text { Stevan.gatot@gmail.com }}{ }^{1}$, Dodik_jatmika@yahoo.com ${ }^{2}$
}

\begin{abstract}
This research aims to determine: (1) the effect of the members number on the remaining business results (SHU), (2) the effect of the loans amount on the remaining business results, (3) the effect of the working amount capital on the remaining business results (SHU), (4) Number of Members, Amount of Loans, and Amount of Working Capital, to Remaining Business Results (SHU) under the auspices of the 2016 micro business and labor cooperative office in Kediri.The research population consisted of 64 cooperatives in 2016 spread over 3 sub-districts in Kediri City. Data collection method with documentation. The data analysis techniques used include 1) Classic Assumption Test which includes Normality Test, Linearity Test, Multicollinearity Test, Autocorrelation Test, Heteroscedasticity Test, 2) Hypothesis Testing using simple regression method, multiple regression, The results showed that: (1) there is no significant partial effect of the variable number of members (X1) on the residual income (Y) of the cooperative in Kediri City, (2) there is no significant partial effect of the variable amount of member loans (X2) on remaining results of business (Y) at the cooperative in Kediri City.
\end{abstract}

Keywords: $\quad$ Number of Members, Amount of Loans, Amount of Capital, and Remaining Business Results

\section{Introduction}

The growth of cooperatives has increased from year to year, but only a few have large assets and business trading volumes. Many cooperatives have many members but their business remains sluggish and most of them go bankrupt. Various studies on the factors that influence SHU have been carried out by previous researchers, such as Ni Kadek Sumita Dewik (2016) with the title "Factors that affect the residual income (SHU) of the Savings and Loan Cooperative (KSP) in North Kuta District, Badung Regency. . Raidayani, Said Muhammad, Faisal (2017) with the title "Factors that affect the residual income (SHU) of cooperatives in West Aceh district". Km Bayu Pariyasa, Anjumanzukhri, Luh Indrayani (2014) with the title "Influence of capital volume and number of members on the remaining business results in multi-business cooperatives in Buleleng sub-district". Monica Triya Cahyani (2015) with the title "'" The effect of the number of members on the acquisition of business results through member participation as an intervening variable in the Graduation Savings and Loans Cooperative for Raharja Denpasar 2012-2014 ". Yuni Nurmawati (2015) with the title "The influence of the number of members, the amount of savings, the amount of loans, and the amount of capital of the church on the remaining business results (shu) in the savings and loan cooperative (Ksp) under the cooperative and umkm office of Kulon Progo Regency 2011-2014" However, from research conducted by Km Bayu Pariyasa, Anjumanzukhri, Luh Indrayani (2014), it is contradictory to other studies, namely that the number of members partially does not affect the remaining results of the business. Thus the inconsistency of previous research occurred, the researchers intended to carry out further 
research on cooperatives in Kediri district with the variables of the number of members, the amount of loans, the amount of working capital, and the SHU.

Growth in the number of members in the cooperative has been slow. This is due to the lack of participation of members on information in the cooperative, so that the cooperative is still very difficult to develop. Second, the problems that arise in terms of savings. Limited capital in the cooperative makes it difficult to develop business units which are expected to improve the welfare of its members. Third, the problem of providing loans. Lending is limited because capital is also limited. In addition, poor use of capital can also hinder the increase in SHU in cooperatives. Fourth, working capital is not good. Working capital is capital that always rotates in a cooperative and every turnover will generate income for the cooperative. If the working capital is not good, it will have an impact on the income the cooperative will receive.

Kediri Regency is a district that is actively developing the regional economy, one of which is with cooperatives and MSMEs. This can be seen from the number of MSMEs in Kediri that use cooperative services as their main capital to develop their business. Of course it is an interesting consideration for researchers because based on the data obtained by researchers, not all cooperatives have maximum performance or the SHU obtained is not optimal so that researchers are interested in conducting research with the title "The influence of variable number of members, number of member loans, and working capital on the remaining results of the cooperative's business. in Kediri City "

The reason why researchers are interested in taking the SHU theme is because SHU adheres to a cooperative system that aims to improve the welfare of its members. Which profits or profits from the cooperative will also return to its members in accordance with the loans that have been made by the members? The bigger or the more savings made by the members, the greater the SHU they will receive. In this study, the researcher wanted to know which effect was the most significant in influencing the amount of SHU from the factors of the number of members, the amount of loans and the amount of working capital.

\section{Literature Review}

a. Notion of Coorperative

According to the cooperative law No.25 of 1992 article 1, cooperatives come from the English language, namely co and operation. Co means joint and operation means effort. If the two words are linked together, it becomes a joint effort. It can be concluded that the definition of a cooperative is a business entity whose members are individuals or a cooperative legal entity by carrying out its activities based on the cooperative principle as well as a people's economic movement based on the principle of kinship.

The definition of cooperative is seen from the point of view according to several figures, including (Firdaus, 2002: 39):

1) Margono Djojohadikoesoemo

A cooperative is an association of individuals who, with their own ethnic groups, want to work together to advance their economy.

2) Soeriatmadja

A cooperative is an association of people who on the basis of equality as human beings, regardless of religious or political direction, voluntarily enter to fulfill common material needs on a shared responsibility.

3) According to Law No.12 of 1967 
International Journal of Economics, Business, and Accounting Research (IJEBAR)

Peer Reviewed - International Journal

Vol-5, Issue-1, 2021 (IJEBAR)

E-ISSN: 2614-1280 P-ISSN 2622-4771

https://jurnal.stie-aas.ac.id/index.php/IJEBAR

Indonesian cooperatives are people's economic organizations with social characteristics, consisting of people or cooperative legal entities, which constitute an economic arrangement as a joint effort based on the principle of kinship.

\section{b. Remaining Operating Results}

1) Definition of Residual Operating Results (SHU)

According to Law article 45 No.25 of 1992 (Hadikusuma 2000: 105), the meaning of the residual income of a cooperative is the cooperative's income earned in one financial year minus costs, depreciation and other liabilities including taxes in the financial year concerned.

In terms of managerial economic aspects, the remaining business results (SHU) of a cooperative is the difference between the total revenue or total revenue (Total Revenue) with the costs (Total Cost) in a year (Sitio and Tamba, 2001: 87). Meanwhile, according to Revrisond Baswir (2000: 16) states that "SHU after deducting certain costs, will be distributed to members according to their respective service considerations".

2) Distribution of Remaining Operating Results

According to the Cooperative Law No.25 of 1992, article 34 explains that the distribution of the remaining business results (SHU) that comes from the business organized for cooperative members can be distributed to members, while the remaining income from the cooperative business is organized for non-members. , for example, the proceeds from services to third parties may not be distributed to members because this portion is not obtained from the services of the members, the remaining proceeds from this business are used for certain other financing

The use of Social Funds is regulated by the Members' Meeting and can be given, among others, to the poor, orphans or other social enterprises. Zakat can be regulated by the cooperative concerned in the articles of association and other provisions of the cooperative. The use of regional development funds is carried out after holding consultations with the local regional government.

The Accounting Standard Statement (PSAK No.27) states that, the distribution of the remaining income must be made at the end of the accounting period. Amounts allocated other than to cooperatives are recognized as liabilities. In the event that the distribution cannot be carried out because the type and amount of the distribution has not been clearly stipulated in the articles of association or by-laws, but must wait for a member meeting, the remaining income is recorded as the remaining business income and has not been distributed and must be explained in the notes to the financial report.

\section{c. Member}

The large number of members will be useful as additional capital obtained from principal savings and mandatory savings. The status of cooperative members in a cooperative business entity is as owner and user. As owners, members must be able to participate in the annual membership meeting (RAT) and participate in raising capital for cooperative business activities. As users, cooperative members must really take advantage of the business activities carried out by the cooperative. The more economic relations between the members and the cooperative, the more likely the cooperative will develop (Sitio and Tamba, 2001: 87).

\section{d. Loans}

Definition of Member Loans (Credit) Loans are the provision of a certain amount of money from a party (financial institution, person or company) to another party (a person or company) who requires the loan to be repaid within a certain period (Winarno and Ismaya. 
2003: 289) in an amount mutually agreed interest. In collecting SHU, savings and loan cooperatives usually benefit from services and / or profit sharing provided by members in financing activities or business capital loans in collaboration with cooperative members.

\section{Research Method}

\section{a. Research Variable}

The variables in this study are as follows:

The Independent Variable in this study is

$(\mathrm{X} 1)=$ Number of Members

$(\mathrm{X} 2)=$ Loan Amount

$(\mathrm{X} 3)=$ total working capital

Dependent Variable The dependent variable in this study is (Y) Remaining Operating Results (SHU)

\section{b. Research Techniques and Approaches}

The research technique used in this research is ex post facto research. Indriantoro and Bambang (2009: 27), this type of ex post facto research is a study conducted to examine an event that has occurred and then trace back to determine the factors that can cause the incident.

This study took data from the Kediri Cooperative Office, where the Kediri Cooperative Office had compiled the annual RAT (Annual Member Meeting) results that had been submitted by all cooperatives in Kediri City that were associated with SHU (Business Remaining Results).

\section{c. Population and Sample}

The number of samples in this study was determined using the sampling formula from Taro and Yamano or the so-called slovin formula (in Ridwan and Kuncoro, 2007: 44 - 45) as follows:

$$
\begin{array}{lr}
\mathrm{n}=\underset{1+\mathrm{Ne} 2}{\mathrm{~N}} & \begin{array}{r}
\text { Description: } \\
\mathrm{n}=\text { Sample size }
\end{array} \\
\mathrm{N}=\text { population size } & \\
\mathrm{d}=\text { sampling error } &
\end{array}
$$

The researcher used a sampling error of $10 \%$, based on the formula for the number of samples above, the number of samples in this study can be calculated as follows:

$$
\mathrm{n}=\frac{199}{(199 \times 0,12)+1}=\frac{199}{2,99}=66,56
$$

The number of samples calculated using the Slovin 66.56 formula because the questionnaire is more than half (0.5) so it is rounded up, so the number of samples used in this study was 67 cooperatives.

Multiple Regression Analysis in this study used a significance level of 0.05 or 5 percent.

The regression model used is:

$\hat{Y}=b o+b_{2} X_{2}+b_{3} X_{3}+b_{4} X_{4}+e$

\section{Result and Discussion}

a. Partial Effect of Total Members $\left(\mathrm{X}_{1}\right)$ on Remaining Operating Results $(\mathrm{Y})$

The first and second regression tests concluded that the number of members did not have a significant effect on the remaining operating results. However, the results of the second 
International Journal of Economics, Business, and Accounting Research (IJEBAR)

Peer Reviewed - International Journal

Vol-5, Issue-1, 2021 (IJEBAR)

E-ISSN: 2614-1280 P-ISSN 2622-4771

https://jurnal.stie-aas.ac.id/index.php/IJEBAR

hypothesis test are different, namely the corrected $t$-count is better than the first hypothesis test. This indicates that the decision of the researcher to exclude the member loan amount variable $\left(\mathrm{X}_{2}\right)$ from the regression calculation is the right decision. The second hypothesis test has corrected the regression model because it was found that there was a multicollinearity problem in the variable $\mathrm{X}_{2}$ (number of member loans). If the multicollinearity problem still exists, the regression model will not present a proper relationship between the independent variable and the dependent variable.

The results of the calculation show that the positive t-count value is 1.569 with a standardized beta coefficient of 0.118 . This means that the higher the variable number of cooperative members, the higher the residual income. On the other hand, the lower the number of cooperative members, the lower the residual income. The results of this study are in accordance with several previous studies conducted by Pariyasa, zukhri, \& Indrayani (2014), Nurmawati (2015). However, the results of this study are not in accordance with previous research conducted by Dewik (2016), Cahyani (2015), Ayuk (2013), Raidayani, Said \& Faisal (2017), Sudaryanti \& Sahroni (2017).

This difference can be explained based on the type of cooperative business. In savings and loan cooperatives, the presence of members greatly affects the performance of the cooperative because the main resource for moving the main business of a savings and loan cooperative is its members. The greater the number of members in the savings and loan cooperative, the greater the savings and loan transaction activities that can generate profits in the form of residual income. This can be seen in research conducted by Dewik (2016), Cahyani (2015) and research by Sudaryanti \& Sahroni (2017) which are research conducted on savings and loan cooperatives, where their research concludes that the number of members has a partial, positive and significant effect on remaining results of operations.

The results of research on multi-business cooperatives have different results, the results of this study are appropriate and strengthen the results of research by Pariyasa, zukhri, \& Indrayani (2014) and Nurmawati (2015) because they have the same subject, namely multi-business cooperatives. Multi-business cooperatives do not only depend on the continuity of their business on the number of members, but on other business activities, such as trade in consumer goods, production activities and so on. These characteristics make the multi-business cooperative members not the only main resource. which contributes to the remaining results of the business. There are still other factors that contribute to the remaining business results, namely business activities in the form of trade in consumer goods and production activities.

\section{b. Partial Effect of Total Member Loan $\left(\mathrm{X}_{2}\right)$ on Remaining Operating Results (Y)}

The first regression test concludes that the number of member loans $\left(\mathrm{X}_{2}\right)$ does not have a significant effect on the remaining operating results $(\mathrm{Y})$. The regression calculation for this hypothesis test results in a positive calculated value of 1.217 with a significance value of the standardized beta coefficient of 0.443 . This means that it is getting higher variable loan amount for cooperative members, the higher the residual income. In contrast, the lower the loan amount for cooperative members, the lower the remaining income.

The standardized beta coefficient value indicates the closeness of the relationship between the variable member loan amount $\left(\mathrm{X}_{2}\right)$ and the remaining business results, which is 0.443 or $44.3 \%$. However, this value is biased or invalid due to the multicollinearity problem and problems regarding the characteristics of the cooperative business under study. 
International Journal of Economics, Business, and Accounting Research (IJEBAR)

Peer Reviewed - International Journal

Vol-5, Issue-1, 2021 (IJEBAR)

E-ISSN: 2614-1280 P-ISSN 2622-4771

https://jurnal.stie-aas.ac.id/index.php/IJEBAR

The results of the calculation of the classical parameter assumption test found that there is a multicollinearity problem in the regression model caused by the variable number of member savings (X2). Indicators of multicollinearity problems are indicated by the magnitude of the tolerance value and the Variance Inflation Factor (VIF) value. A multiple regression model does not experience multicollinearity problems. If the tolerance value is close to 1 and the VIF value is less than 10. The results of the calculation of the classical parameter assumption test for the variable number of member deposits $\left(\mathrm{X}_{2}\right)$ produce a tolerance value of 0.031 and a Variance Inflation Factor (VIF) value of 31.865.

This reinforces that there has been a multicollinearity symptom because of the correlation between the independent variables, so the variables included in the linear equation are only the independent variables that have errors. In this study the correlation between the independent variables which is the source of the multicollinearity problem occurs in the variable number. member savings $\left(\mathrm{X}_{2}\right)$ and working capital variables $\left(\mathrm{X}_{3}\right)$. This indication is getting stronger when the correlation test is carried out between the variable member savings $\left(X_{2}\right)$ and the working capital variable $\left(\mathrm{X}_{3}\right)$ which results in a correlation coefficient of 0.984 .

This study concludes that there is no significant effect of the variable member savings $\left(\mathrm{X}_{2}\right)$ on the remaining business results $(Y)$. The results of this study reinforce previous research conducted by Ayuk (2013). However, the results of this study contradict the results of research conducted by Dewik (2016), Nurmawati (2015), and Rupitasari, Medinal, \& Panjaitan (2017). Because there is a very strong multicollinearity problem, the researchers conclude that this result contains a significant bias so that the conclusion that there is no significant effect on the variable total member savings $\left(\mathrm{X}_{2}\right)$ on the remaining operating results $(\mathrm{Y})$ must be ignored.

\section{c. Partial Effect of Working Capital $\left(\mathbf{X}_{3}\right)$ on Remaining Operating Results (Y)}

This study concludes that working capital $\left(\mathrm{X}_{3}\right)$ has a significant effect on the remaining results of operations $(\mathrm{Y})$. The results of the first hypothesis test state that working capital $\left(\mathrm{X}_{3}\right)$ does not have a significant effect on the remaining operating results (Y) due to multicollinearity problems, namely the existence of Strong correlation between the independent variables. In this research, there was a variable number of member loans $\left(\mathrm{X}_{2}\right)$ and working capital variables $\left(\mathrm{X}_{3}\right)$ with a correlation coefficient value of 0.984 .

Efforts to correct the correct regression model are presented in the second hypothesis testing model which eliminates the variable number of member loans $\left(\mathrm{X}_{2}\right)$ because of the multicollinearity problem. The results of the second hypothesis test concluded that the working capital variable $\left(\mathrm{X}_{3}\right)$ has a positive effect on the remaining business results. This conclusion is based on the tcount value for 10.557 (positive value) with a standardized beta coefficient of 0.796. This means that if the working capital is higher, the remaining results of the business will be greater. Conversely, if the working capital is lower, the remaining business results will be smaller.

The results of this study strengthen previous research conducted by Pariyasa, zukhri, \& Indrayani (2014), Nurmawati (2015) and research by Raidayani, Said \& Faisal (2017). Even so, Sudarijati (2017) states that this conclusion only applies to working capital from internal members of the cooperative. This does not apply if the capital comes from outside the members in the form of loan capital. The capital itself comes from internal members of the cooperative.

Own capital will add to the remaining operating income because it does not have interest costs, thus adding significantly to the amount of the remaining operating income. Meanwhile, borrowed capital causes interest costs with a certain amount which will reduce the amount of the 
International Journal of Economics, Business, and Accounting Research (IJEBAR)

Peer Reviewed - International Journal

Vol-5, Issue-1, 2021 (IJEBAR)

E-ISSN: 2614-1280 P-ISSN 2622-4771

https://jurnal.stie-aas.ac.id/index.php/IJEBAR

remaining income from the business. This is because with more working capital, the cooperative will be able to make various efforts to increase the remaining results of its business. The amount of capital owned by the cooperative is well available so that the cooperative is able to finance all the company's operational activities (Sawir, 2005).

\section{d. The Simultaneous Effect of Total Members $\left(X_{1}\right)$, Number of Loan Members $\left(X_{2}\right)$, and Working Capital $\left(\mathbf{X}_{3}\right)$ on Remaining Operating Results (Y)}

This study concludes that there is a simultaneous significant influence on the number of members $\left(\mathrm{X}_{1}\right)$, the number of member loans $\left(\mathrm{X}_{2}\right)$, and working capital $\left(\mathrm{X}_{3}\right)$ on the remaining business results (Y). The results of this study reinforce previous research conducted by Dewik (2016). , Nurmawati (2015), and Ayuk (2013). The first and second hypothesis tests concluded the same results, namely that there was a simultaneous significant effect of the independent variables on the remaining operating results $(\mathrm{Y})$. The results of the first hypothesis test resulted in the value of Fcount $=60.306$ with a value of Rsquare $=0.751$. Correction by issuing the variable number of member loans $\left(\mathrm{X}_{2}\right)$ is expected to present a more precise regression model regarding the pattern of closeness of the relationship between the independent variable and the dependent variable. The results of the second hypothesis test result in the Fcount and Rsquare values that are different from the first hypothesis, namely Fcount $=89.017$ with a value of Rsquare $=0.745$.

The dependent variable in this research is the residual results of operations (SHU). The remaining results of operations are net income as is common in the business world which is reported at the end of each period. According to AminTunggal Wijaya (2002: 38), "The remainder of the cooperative's operating income is the cooperative's income earned in one year, less depreciation and expenses from the relevant financial year or commonly referred to as net profit". Sumarsono (2001: 87) argues that: "SHU is the income earned in one financial year less depreciation costs, and other liabilities including taxes in the financial year concerned". Meanwhile Baswir (2000: 16) states that, "SHU after deducting certain costs, will be distributed to members according to their respective service considerations".

The amount of SHU depends on the activities carried out by the cooperative itself. Pachta, et al (2005), explained that the factors that influence SHU consist of two factors, namely: external factors and internal factors. External factors include: 1) Loan capital from outside, 2) Outside consumers other than cooperative members, and 3) Government. Meanwhile, internal factors include: 1) member participation, 2) total equity, 3) management performance, 4) number of business units owned, 5) manager performance, 6) employee performance.

Slightly different from pachta, the factors that influence SHU according to Iramani and Kristijadi, (1997) are 4. First, the number of cooperative members. The more members of the cooperative who save funds in the cooperative, it is hoped that it will increase the volume of cooperative activities so that it will increase the SHU that the cooperative will get. The second factor is the volume of the business. The increase in SHU of a cooperative is very dependent on the activities it carries out, so the aspect of the volume of business carried out by the cooperative will greatly determine its income. The third factor is the amount of savings. The savings of the members of the cooperative are one of the components that participate in determining the activities of the cooperative in the cooperative. The fourth factor is the amount of debt or loans. The business volume that must be increased by the cooperative will implement sufficient capital, both from members and capital excavated from outside (debt).

\section{Conclusion and Suggestion}


International Journal of Economics, Business, and Accounting Research (IJEBAR)

Peer Reviewed - International Journal

Vol-5, Issue-1, 2021 (IJEBAR)

E-ISSN: 2614-1280 P-ISSN 2622-4771

https://jurnal.stie-aas.ac.id/index.php/IJEBAR

\section{Conclusion}

The conclusions produced by this research:

a. There is no significant partial effect of the variable number of members $\left(\mathrm{X}_{1}\right)$ on the residual income (Y) of the cooperative in Kediri City

b. There is no significant partial effect of the member variable loan amount $\left(\mathrm{X}_{2}\right)$ on the remaining business results (Y) at the cooperative in Kediri City. However, in this study the variable of the number of member loans $\left(\mathrm{X}_{2}\right)$ has a multicollinearity problem, so that its existence in the regression model can be ignored.

c. There is a significant partial effect of working capital variables $\left(\mathrm{X}_{3}\right)$ on the remaining results of operations (Y) in cooperatives in Kediri City. This influence is positive.

d. There is a significant simultaneous effect of the number of members $\left(\mathrm{X}_{1}\right)$, the number of member loans $\left(\mathrm{X}_{2}\right)$, and working capital $\left(\mathrm{X}_{3}\right)$ on the remaining operating results $(\mathrm{Y})$. Due to the multicollinearity problem, the variable member loan amount $\left(\mathrm{X}_{2}\right)$ was excluded from the regression model.

\section{Suggestion}

Based on the results of the research conclusions, the following suggestions are proposed:

a. It is recommended that cooperative managers in the Kediri increase working capital for operations in order to obtain an increase in the residual income of the business, so as to improve the welfare of its members.

b. It is recommended to further researchers who are interested in similar themes, to conduct research by limiting the types of cooperatives, such as savings and loans, multi-business cooperatives, size of cooperatives based on the number of members, the amount of working capital, and so on in order to obtain better research results.

\section{References}

Ayuk, Ni Made Taman (2013. Pengaruh Jumlah Anggota Jumlah Simpanan, Jumlah Pinjaman dan Jumlah Modal Kerja Terhadap SHU koperasi Simpan Pinjam Kabupaten Badung Provinsi bali. Jurnal: universitas Udayana Bali http//jbptunikompp-gdl-irfandwiad-224901-artikel, (diunduh 19 Agustus 2018)

Baswir, Revrisond, 2000. Koperasi Indonesia, Yogyakarta : BPFE - Yogyakarta

Baswir, Revrisond. 1997. Koperasi Indonesia Edisi Pertama. Yogyakarta : BPFE.

Baswir, Revrisond. 2012. Koperasi Indonesia. Yogyakarta: BPFE

Cahyani, Monica Tria. 2015. Pengaruh Jumlah Anggota Terhadap Perolehan Sisa Hasil Usaha Melalui Partisipasi Anggota Sebagai Variabel Intervening Pada Koperasi Simpan Pinjam Wisuda Gunaraharja Denpasar Tahun 2012- 0 ". Jurnal Jurusan Pendidikan Ekonomi (JJPE) Universitas Pendidikan Ganesha Singaraja, Indonesia. Volume. 5, No. 1, Hal 110.

Dewik, Ni Kadek Sumita \& Jember, I Made. 2016. Faktor-Faktor Yang Mempengaruhi Sisa Hasil Usaha (SHU) Koperasi Simpan Pinjam (KSP)Di Kecamatan Kuta Utara Kabupaten Badung. E-jurnal Ekonomi Pembangunan Universitas Udayana Vol.V , No.7Juli 2016

Firdaus, Muhammad, dan Susanto, Agus Edhi. 2002. Perkoperasian :Sejarah, Teori dan Praktek. Jakarta : Ghalia Indonesia

Ghozali, Imam. 2009. Aplikasi Analisis Multivariate dengan Program SPSS. Edisi Keempat Semarang: Badan Penerbit universitas Diponegoro.

Hendrojogi. 2007. Koperasi :Asas-Asas, Teoridan Praktik. Jakarta: PT. Raja Grafindo Persada Indriyo, Gitosudarmo, dan Basri, 2000, Manajemen Keuangan Edisi Ketiga, BPFE, Yogyakarta. 
International Journal of Economics, Business, and Accounting Research (IJEBAR)

Peer Reviewed - International Journal

Vol-5, Issue-1, 2021 (IJEBAR)

E-ISSN: 2614-1280 P-ISSN 2622-4771

https://jurnal.stie-aas.ac.id/index.php/IJEBAR

Indriyo,Gitosudarmo. 2002. Manajemen Keuangan. Yogyakarta : BPFE.

Iramani dan Kristijadi, E. 1997. Faktor-Faktor Yang Mempengaruhi SisaHasil Usaha Koperasi Unit Desa di Jawa Timur. Jurnal Ventura: Vol. 1, No. 2, hal 73-79.

Kasmir.2008. Bank dan Lembaga Keuangan Lainnya Edisi Revisi 2008. Jakarta: PT. RAJA GRAFINDO PERSADA.

Nugroho.2005. Statistik Teori dan Aplikasi. Jakarta : Erlangga

Nurmawati, Yuni. 2015. Pengaruh Jumlah Anggota, Jumlah Simpanan, Jumlah Pinjaman Dan Jumlah Modal Kerja Terhadap Sisa Hasil Usaha (Shu) Pada Koperasi Simpan Pinjam (Ksp) Yang Bernaung Di Bawah Dinas Koperasi Dan Umkm Kabupaten Kulon ProgoTahun 2011-2014. Skripsi. Program Studi Akuntansi Fakultas Ekonomi Universitas Negeri Yogyakarta:

Pachta, W Andjar, dkk.2005. Hukum Koperasi Indonesia. Jakarta: Kencana Prenada Group

Pachta, W Andjar.dkk. 2005. Manajemen Koperasi : Teori dan Praktik. Yogyakarta : Graha Ilmu.

Pariyasa, Bayu Km;Zukhri, Anjuman; dan Indrayani, Luh, 2014.Pengaruh Modal, Volume Dan Anggota Terhadap Sisa Hasil Usaha Pada Koperasi Serba Usaha Kecamatan Buleleng, Jurusan Pendidikan Ekonomi Universitas Pendidikan Ganesha Singaraja, Indonesia Vol: 4 No: 1

Raidayani, Said Muhammad, Faisal (2017. Faktor-faktor Yang Mempengaruhi Sisa Hasil Usaha (SHU) Pada Koperasi Di Kabupaten Aceh Barat. Jurnal Perspektif Ekonomi Darussalam Volume 3 Nomor 2, September 2017. Diterbitkan oleh program studi ekonomi universitas syiah kuala

Rohmansyah, Tria \& Sudarijati.2017. Pengaruh Modal Sendiri Dan Modal Pinjaman Terhadap Sisa Hasil Usaha (SHU) Koperasi Kota Sukabumi. Jurnal Visionida, Volume 3 Nomor 1, Desember 2017.Program Studi Manajemen Fakultas Ekonomi Universitas Djuanda Bogor

Rupitasari, Riya; Medinal, \& Panjaitan, Fery.2017. Analisis Pengaruh Jumlah Simpanan Anggota, Jumlah Pinjaman Anggota Dan Modal Kerja Terhadap Sisa Hasil Usaha (SHU): Studi Kasus Pada Koperasi Karyawan PT Pelindo II Cabang Pangkalbalam”. Jurnal Ilmiah Akuntansi Bisnis \& Keuangan(JIABK), Volume11, Nomor 2, November 2017ISSN 23559047. STIE-IBEK Bangka Belitung Pangkal Pinang, Indonesia

Sawir, Agnes. 2005. Pengertian Modal Kerja. Jakarta :PT. Gramedia Pustaka Utama

Sawir.2005. Pengertian Modal Kerja. Jakarta :PT. Gramedia Pustaka Utama

Sitio, Arifin dan Halomoan Tamba, 2001.Koperasi : Teori dan Praktek, Penerbit: Erlangga, Jakarta.

Sudaryanti, Dedeh Sri, \&Sahroni, Nana. 2017. Pengaruh Jumlah Anggota, Modal Luar, Dan Total Asset Terhadap SisaHasil Usaha "Studi Empiris pada Koperasi Simpan Pinjam di Kota Tasikmalaya".Ekspektra: “Jurnal Bisnis dan Manajemen, Volume 1, Nomor 2, Hal. 156-172 e-ISSN: 2549-3604, p-ISSN: 2549-6972 (Online) http://dx.doi.org/ 10.25139/ekt.v0i0.339, Diakses 19 Agustus 2018.

Sudirman. 2000. Teori Ekonomi Mikro I. Yogyakarta : Universitas Terbuka.

Sugiyono, 2014.Metode penelitian kuantitatif, kualitatif dan R \& D. Alfabeta. Bandung. 